\title{
Milk protein concentration, estimated breeding value for fertility, and reproductive performance in lactating dairy cows
}

\author{
John M. Morton, ${ }^{* 1}$ Martin J. Auldist, $†$ Meaghan L. Douglas, $†$ and Keith L. Macmillan $\ddagger$ \\ *Jemora Pty Ltd., Geelong, Victoria 3220, Australia \\ †Department of Economic Development, Jobs, Transport, and Resources, Ellinbank Centre, Victoria 3821, Australia \\ †Department of Veterinary and Agricultural Sciences, The University of Melbourne, Werribee, Victoria 3030, Australia
}

\begin{abstract}
Milk protein concentration in dairy cows has been positively associated with a range of measures of reproductive performance, and genetic factors affecting both milk protein concentration and reproductive performance may contribute to the observed phenotypic associations. It was of interest to assess whether these beneficial phenotypic associations are accounted for or interact with the effects of estimated breeding values for fertility. The effects of a multitrait estimated breeding value for fertility [the Australian breeding value for daughter fertility (ABV fertility)] on reproductive performance were also of interest. Interactions of milk protein concentration and $\mathrm{ABV}$ fertility with the interval from calving date to the start of the herd's seasonally concentrated breeding period were also assessed. A retrospective single cohort study was conducted using data collected from 74 Australian seasonally and split calving dairy herds. Associations between milk protein concentration, ABV fertility, and reproductive performance in Holstein cows were assessed using random effects logistic regression. Between 52,438 and 61,939 lactations were used for analyses of 4 reproductive performance measures. Milk protein concentration was strongly and positively associated with reproductive performance in dairy cows, and this effect was not accounted for by the effects of ABV fertility. Increases in ABV fertility had important additional beneficial effects on the probability of pregnancy by wk 6 and 21 of the herd's breeding period. For cows calved before the start of the breeding period, the effects of increases in both milk protein concentration and ABV fertility were beneficial regardless of their interval from calving to the start of the breeding period. These findings demonstrate the potential for increasing reproductive performance through identifying the causes of the association between milk protein concentration and reproductive
\end{abstract}

Received April 5, 2016.

Accepted March 6, 2017.

${ }^{1}$ Corresponding author: john.morton@optusnet.com.au performance and then devising management strategies to capitalize on them. Research should be conducted to understand the component of the relationship not captured by ABV fertility.

Key words: milk protein concentration, breeding value, genetics, reproductive performance

\section{INTRODUCTION}

Milk protein concentration in dairy cows has been positively associated with a range of measures of reproductive performance in both seasonally calving (Buckley et al., 2003; Xu and Burton, 2003) and yearround calving (Opsomer et al., 2000; Madouasse et al., 2010) herds. The association between milk protein concentration and reproductive performance is probably due to both genetic and nongenetic mechanisms. Milk protein concentration is heritable (Haile-Mariam and Goddard, 2008) but is also affected by nutritional and other environmental factors (Barber, 2007). In Australia, breeding values for fertility are estimated using Australian breeding values for daughter fertility (ABV fertility), which are derived using a multitrait model (Pryce et al., 2013). Initial analyses of data derived from Holstein cows in seasonally calving herds showed that milk protein concentration and $\mathrm{ABV}$ fertility were both positively associated with measures of reproductive performance (Morton, 2011). It is not known whether the association between milk protein concentration and reproductive performance is accounted for by, or interacts with, ABV fertility. In addition, no previous assessment has been made on whether these associations (between milk protein concentration and reproductive performance and between $\mathrm{ABV}$ fertility and reproductive performance) vary in the same way with the interval from each cow's calving date to the start of the herd's breeding period. A feature of breeding programs in seasonally calving herds is that there is no voluntary waiting period; any cow detected in estrus following the start of the herd's intensive breeding period is submitted for an insemination regardless of her interval from calving. Finally, there was a need 
to compare the relative effects of milk protein concentration and of $\mathrm{ABV}$ fertility on the probabilities of the cow being submitted for insemination in the first $3 \mathrm{wk}$ of the herd's seasonally concentrated breeding period and conceiving to first service. These 2 measures have major influences on the percentage of cows in the herd that become pregnant in the first 6 wk of the breeding period (6-wk in-calf rate; Morton, 2010). Collectively, these analyses would provide information about the similarity of causes of these 2 associations and indicate the possibility of developing an algorithm that classified cows within a herd into risk categories for submission and conception using the associations involving milk protein concentration, $\mathrm{ABV}$ fertility, and the interval from calving to the start of a herd's breeding period.

The objectives of this study were (1) to estimate the strengths of the association between milk protein concentration and reproductive performance of Holstein cows in herds with seasonally concentrated breeding programs after adjusting for the cows' ABV fertility, (2) to assess interactions between the effects of milk protein concentration and ABV fertility, (3) to estimate effects of ABV fertility on reproductive performance, and (4) to identify any interactions involving milk protein concentration or ABV fertility with the cow's interval from calving date to the start of the herd's breeding period. These effects were assessed on both probabilities of submission by wk 3 of the breeding period and conception to first service along with probabilities of pregnancy in the first 6 and 21 wk of the breeding period.

\section{MATERIALS AND METHODS}

\section{Study Overview}

A retrospective single cohort study was conducted using data collected from 74 Australian dairy herds. Full details of the study have been reported previously (Morton et al., 2016). Briefly, in 2010, veterinarians from 4 practices in Victoria and Tasmania were asked to select commercial client herds with accessible electronically stored data that met the study's herd selection criteria. The primary criteria were (1) adequate whole-herd early ultrasound or manual rectal pregnancy testing and (2) complete and accurate data in an electronic database. In addition, all herd years with sufficient early pregnancy test data in the Australian Dairy Herd Improvement Scheme (ADHIS) national database (http://www.adhis.com.au) were identified and selected.

Every selected herd was seasonally or split calving (i.e., they had either 1 or 2 to 3 restricted calving periods each year, respectively). Most used AI exclusively for an initial period of several weeks before running bulls with the lactating herd. Breeding period commencement dates were determined within each herd based on the daily numbers of services (i.e., AI and natural services). Because dates that bulls were removed from the lactating herds and bull services generally were not recorded, end dates for each herd's breeding period were defined based on conception dates determined from results of rectal ultrasound or manual pregnancy diagnoses. Conception dates were calculated from estimated stages of pregnancy from positive pregnancy diagnoses in combination with dates of inseminations and any recorded bull services.

Each study cow could contribute multiple calvings and the consequent lactations. Breeding period start dates were identified for each herd in each year based on $\mathrm{AI}$ and natural service data. All lactations by Holstein cows commencing between $120 \mathrm{~d}$ before and $30 \mathrm{~d}$ after the nearest breeding period start date were selected and allocated the nearest breeding period start date. When the herd had 2 breeding periods commencing $120 \mathrm{~d}$ apart or less, calvings between these start dates were allocated to the second breeding period start date. Other lactations were excluded from analyses. Lactations in which arbitrary calving dates had been recorded (e.g., all calvings for the herd recorded as occurring on the first day of the calendar month) were also excluded from analyses, as were lactations with services or conception dates before the breeding period start date. Breeding periods were considered to have adequate data for analyses only if they had been allocated more than 50 lactations, and for more than $80 \%$ of those lactations, the cow had at least 1 pregnancy diagnosis.

Four lactation-level binary reproductive performance measures were used as dependent variables:

- submitted (i.e., served) by wk 3 of the breeding period,

- conception to first service (for lactations in which the first service was by AI),

- pregnancy by wk 6 of the breeding period, and

- pregnancy by wk 21 of the breeding period (pregnancy by the end of the breeding period considering only pregnancies up to the end of wk 21 of the breeding period).

For each reproductive measure, all selected lactations were included if the cow's status for that measure could be ascertained. For example, submitted by wk 3 of the breeding period could be ascertained only for cows not culled by that time, and pregnancy by wk 6 of the breeding period could be ascertained only for cows diagnosed as pregnant or those whose final pregnancy 
test was at least $70 \mathrm{~d}$ after the start of the breeding period.

\section{Milk Protein Concentrations}

Milk protein concentrations and milk yields had been measured by commercial milk recording services. Milk protein concentrations were calculated for the first $120 \mathrm{~d}$ of each lactation using these 24-h milk recording data. For each 24-h estimate, 24 -h protein yields were calculated as milk protein concentration for that 24-h period multiplied by milk yield for that period. All estimates until $120 \mathrm{~d}$ after calving and the next 24 -h estimate were used to calculate 120 -d values. Milk protein concentration was calculated as 120 -d protein yield divided by $120-\mathrm{d}$ milk yield. These were calculated, respectively, as areas under the lactation curves of 24 -h protein yield and milk yield by time from calving. Lactation curves were defined assuming constant 24-h yields and yields from calving to first milk recording and linear interpolation between milk recordings. Lactations in which 120 -d milk protein concentration was $8 \%$ or higher were excluded from analyses.

\section{Fertility Breeding Values}

Each cow's fertility breeding value was calculated using ABV fertility values of sires and maternal grandsires as calculated by ADHIS on April 13, 2015. These had been calculated with a multitrait model that used calving interval, calving to first service interval, lactation length, nonreturn to service, and diagnosis of pregnancy (Pryce et al., 2013) and had been standardized relative to a base of 100 .

For cows whose sire and maternal grandsire identities were available, the cow's ABV fertility was calculated as

$$
\begin{gathered}
0.5 \times \text { sire } \mathrm{ABV} \text { fertility }+0.25 \times \text { maternal } \\
\text { grandsire } \mathrm{ABV} \text { fertility }+0.25 \times 100 .
\end{gathered}
$$

For cows whose sire identity was available but maternal grandsire identity was not available, the cow's ABV fertility was calculated as

$$
0.5 \times \text { sire ABV fertility }+0.5 \times 100 \text {. }
$$

We used ABV fertility values of sires rather than $A B V$ fertility values estimated directly for cows. When calculated, these latter $\mathrm{ABV}$ values incorporate the cow's own phenotypic reproductive performance. Consequently, they were unsuitable for use when the aim was to estimate the effects of ABV fertility on the cows' phenotypic reproductive performances.

\section{Statistical Analyses}

Analyses were completed using Stata (versions 13 and 14; StataCorp, College Station, TX). For descriptive purposes, numbers of lactations and percentages of these resulting in each reproductive outcome were calculated for various combinations of milk protein concentration, ABV fertility, and interval from calving date to the start of the herd's breeding period categories.

Associations with the 4 binary dependent variables were assessed using logistic regression with the individual lactation as the unit of analysis. When fitting continuous exposure (i.e., independent) variables in logistic models, one assumes that the relationship is linear on the logit scale (i.e., that the log odds of the event increase linearly with the continuous exposure variable). This assumption of linearity in the logit between milk protein concentration and each reproductive outcome variable was assessed by visual assessment of locally weighted regression (lowess) plots after lowess regression of each reproductive outcome on milk protein concentration; smoothed probabilities were transformed into logits before plotting. Stata's -lowess- command was used. Linearity in the logit between ABV fertility and each reproductive outcome was assessed in the same way. Associations between milk protein concentrations at most stages of lactation and reproductive performance measures were approximately linear in the logit over the range of the most common milk protein concentrations of 2.75 to $3.75 \%$. Also, ABV fertility was approximately linear in the logit with all reproductive outcomes over the range of most common values (95-105). Accordingly, milk protein concentration and ABV fertility were both fitted as continuous variables in statistical models.

Random effects logistic regression models were used with herd fitted as a random effect using the -xtlogitcommand in Stata. Associations between milk protein concentration and each reproductive outcome were assessed without and with ABV fertility fitted as a covariate. Cow age at calving, source of data, year of the start of the breeding period, and interval from calving to the start of the herd's breeding period date (linear and quadratic terms) were also fitted as covariates as used previously (Morton, 2011). For conception to first service, linear and quadratic terms for the interval from calving to the start of the herd's breeding period date were replaced with linear and quadratic terms for calving to service interval. Source of data had 7 categories: 
each of the 4 veterinary practices and, for herds sourced from ADHIS, herd region (Gippsland, South West Victoria, or Northern Victoria). Interactions between milk protein concentration and ABV fertility were assessed with both main effects and the same covariates also fitted concurrently. For each reproductive outcome, likelihood ratio test $P$-values were used to assess the interaction terms. Odds ratios for a 1-percentage-point increase in milk protein concentration were estimated at ABV fertility values of 95, 100, and 105 (approximately the 5th, 50th, and 95th percentiles, respectively). Probabilities of each reproductive outcome were predicted from these models for various milk protein concentrations using Stata's -margins- command. Main effects of ABV fertility were assessed in the same way as used for milk protein concentration. For milk protein concentration and $\mathrm{ABV}$ fertility, joint $P$-values for interactions with interval from calving date to the start of the herd's breeding period were assessed after fitting interactions with both linear and quadratic terms. For simplicity in communicating results, interval from calving date to the start of the breeding period was fitted as a categorical variable in place of the linear and quadratic terms.

Associations between milk protein concentration and each reproductive outcome assessed without and with ABV fertility fitted as a covariate are both reported. This allowed identification of important confounding by $\mathrm{ABV}$ fertility, as indicated by the magnitude of change in the odds ratio point estimate when it was adjusted for $\mathrm{ABV}$ fertility. Interaction $P$-values are also reported. To facilitate further assessment of any interaction between milk protein concentration and $\mathrm{ABV}$ fertility in their effects on the reproductive outcome, effects of milk protein concentration are reported at various $\mathrm{ABV}$ fertility values. As ABV fertility was fitted as a continuous variable, it was possible to show the estimated effects of milk protein concentration at any ABV fertility values one may choose. We used 3 realistic values (i.e., values reflecting the common spread of ABV fertility but not extreme values): 95, 100, and 105. The purpose of these was not to identify ABV fertility values at which effects of milk protein concentration differ. Where there was evidence of interaction (based on a low interaction $P$-value), the effects of milk protein concentration are affected even by small differences in ABV fertility. Where the interaction $P$-value was high, the effect estimates for milk protein concentration at various $\mathrm{ABV}$ fertility values are reported to provide information about any differences in effects of milk protein concentration at various ABV fertility not detected based on the interaction $P$-value. We reported estimated effects of milk protein concentration at various intervals from calving to the start of the herd's breeding period for the same reason.
Effects of milk protein concentration adjusted for ABV fertility and interactions between milk protein concentration and ABV fertility were also assessed with analyses restricted to lactations from cows whose maternal grandsire's ABV fertility was known (approximately $70 \%$ of all otherwise eligible lactations). These results were very similar to those in which lactations from cows were included regardless of whether their maternal grandsire's ABV fertility was known; the largest absolute change in odds ratio when analyses were restricted to lactations from cows whose maternal grandsire's ABV fertility was known was 0.16 , and most differences were $<0.10$. Accordingly, these additional results are not reported.

\section{Numbers of Herds and Lactations}

The 4 veterinary practices selected 58 herds, and 20 herds were selected from the ADHIS national database. Four herds were selected in both sources, so 74 unique herds were selected. One herd was subsequently excluded because substantial numbers of cows and calvings had not been entered into the database. The remaining 73 herds provided data for 126,277 cows; these cows had 359,892 calvings (and hence lactations) recorded. Exclusions sequentially were as follows:

- Lactations not commencing on or between $120 \mathrm{~d}$ before and $30 \mathrm{~d}$ after a breeding period start date in the herd ( $\mathrm{n}=86,824$, leaving 273,068)

- Duplicated lactations ( $\mathrm{n}=4,246$, leaving 268,822$)$

- Breeding period did not have adequate data for analyses ( $\mathrm{n}=84,371$, leaving 184,451)

- Lactations allocated to 4 breeding period start dates as arbitrary calving dates had been recorded $(\mathrm{n}=1,362$, leaving 183,089)

- Cow not recorded as Holstein ( $\mathrm{n}=94,594$, leaving $88,495)$

- Date of birth not recorded for cow ( $\mathrm{n}=1,343$, leaving 87,152 )

- Reproductive outcome could not be determined (for pregnant by wk $6, \mathrm{n}=2,731$, leaving 84,421 )

- Milk protein concentration not available or $\geq 8 \%$ $(\mathrm{n}=22,067$, leaving 62,354)

- The ABV fertility could not be calculated because the cow's sire's identity was not recorded $(\mathrm{n}=$ 613 , leaving 61,741)

These 61,741 lactations were used for analyses of the association between milk protein concentration and pregnancy by wk 6. Maternal grandsire ABV fertility values were available for $72 \%(44,591 / 61,741)$ of these lactations. The 61,741 lactations were from 24,450 cows 
Table 1. Percentages of lactations in which the cow was submitted by wk 3 of the herd's breeding period based on milk protein concentration (milk protein percentage) for the first $120 \mathrm{~d}$ of each lactation and the cow's EBV for fertility (Australian breeding value for daughter fertility or ABV fertility)

\begin{tabular}{lcccccc}
\hline & \multicolumn{5}{c}{ ABV fertility } \\
\cline { 2 - 7 } Milk protein (\%) & $<95$ & 95 to $<97.5$ & 97.5 to $<100$ & 100 to $<102.5$ & $\geq 102.5$ & Pooled \\
\hline$<2.75$ & $46.9^{1}$ & 50.0 & 52.0 & 56.4 & $43.9^{1}$ & 52.4 \\
2.75 to $<3.00$ & 53.1 & 54.3 & 58.5 & 63.9 & 62.2 & 60.0 \\
3.00 to $<3.25$ & 61.9 & 62.8 & 63.1 & 68.6 & 70.7 & 65.8 \\
3.25 to $<3.50$ & 65.3 & 67.4 & 68.4 & 71.6 & 75.9 & 70.2 \\
3.50 to $<3.75$ & $56.2^{1}$ & 71.9 & 72.6 & 74.5 & 75.6 & 73.3 \\
$\geq 3.75$ & $72.4^{1}$ & $78.6^{1}$ & 74.7 & 75.2 & $82.7^{1}$ & 76.4 \\
Pooled & 60.0 & 63.4 & 64.6 & 69.1 & 71.6 & 66.7 \\
\hline
\end{tabular}

${ }^{1}$ Denominator (number of lactations) was $<250$; numbers varied from 29 to 173 . Denominators for other nonpooled cells varied from 254 to 9,205 (total $\mathrm{n}=61,939$ ).

in 63 herds. Numbers varied for other reproductive outcomes.

\section{RESULTS}

\section{Milk Protein Concentration-Reproductive Performance Association and ABV Fertility}

For all 4 reproductive outcomes, strong positive associations were evident between milk protein concentration and reproductive performance within various $A B V$ fertility categories using crude data, and the strengths of the association between milk protein concentration and reproductive performance changed minimally after adjustment for ABV fertility. This indicates that the associations between milk protein concentration and reproductive performance were not accounted for by (and thus were largely independent of) ABV fertility.

\section{Submission by Wk 3}

Milk Protein Concentration. Proportions of cows that were submitted by wk 3 increased markedly with milk protein concentration (Tables 1 and 2; Figure 1).
The strength of association (as measured by odds ratios) was greater among cows with lower ABV fertility values (interaction $P=0.008$ ), but positive associations were evident at every ABV fertility value that was assessed.

In contrast, odds ratios for effects of milk protein concentration were similar for cows calved at various intervals before the start of the herd's breeding period, varying from 1.80 to 2.32 (results not shown). The $P$ value for the interaction between milk protein concentration and this interval was 0.638 . For lactations in which the cow calved after the start of the breeding period, the odds ratio estimate was 1.31 but very imprecise (95\% CI: 0.43-3.98).

$A B \boldsymbol{V}$ Fertility. Crude percentages of lactations in which the cow was submitted by wk 3 for cows with ABV fertility values of $<95,95$ to $<97.5,97.5$ to $<100$, 100 to $<102.5$, and $\geq 102.5$ were $60.0,63.4,64.6,69.1$, and $71.6 \%$, respectively (Table 1 ). The $P$-value for the interaction between $\mathrm{ABV}$ fertility and interval from calving date to the start of the herd's breeding period was 0.045 . The adjusted odds ratio for a 2.5 -unit increase in ABV fertility was 1.09 (95\% CI: 1.06-1.10; $P$ $<0.001$ ). Odds ratios were similar for the most com-

Table 2. Effects of a one-percentage-point increase in milk protein concentration at selected values for the cow's EBV for fertility (Australian breeding value for daughter fertility or ABV fertility) on odds of submission by wk 3 of the herd's breeding period

\begin{tabular}{lccc}
\hline ABV fertility & Adjusted odds ratio & $95 \% \mathrm{CI}$ & $P$-value \\
\hline All ABV fertility values pooled & & & \\
Not adjusted for ABV fertility & 2.02 & $1.85-2.20$ & $<0.001$ \\
Adjusted for ABV fertility & $1.99^{2}$ & $1.83-2.17$ & $<0.001$ \\
95 & $2.47^{3}$ & $2.06-2.95$ & $<0.001$ \\
100 & $1.94^{3}$ & $1.78-2.12$ & $<0.001$ \\
105 & $1.53^{3}$ & $1.23-1.89$ & $<0.001$ \\
\hline
\end{tabular}

${ }^{1}$ Adjusted for cow age at calving, source of data, year of herd's breeding period start date, and interval from calving date to the start of the herd's breeding period (linear and quadratic terms); herd was fitted as a random effect.

${ }^{2}$ Also adjusted for ABV fertility.

${ }^{3}$ Interaction between milk protein concentration and ABV fertility fitted (interaction $P=0.008$ ). 

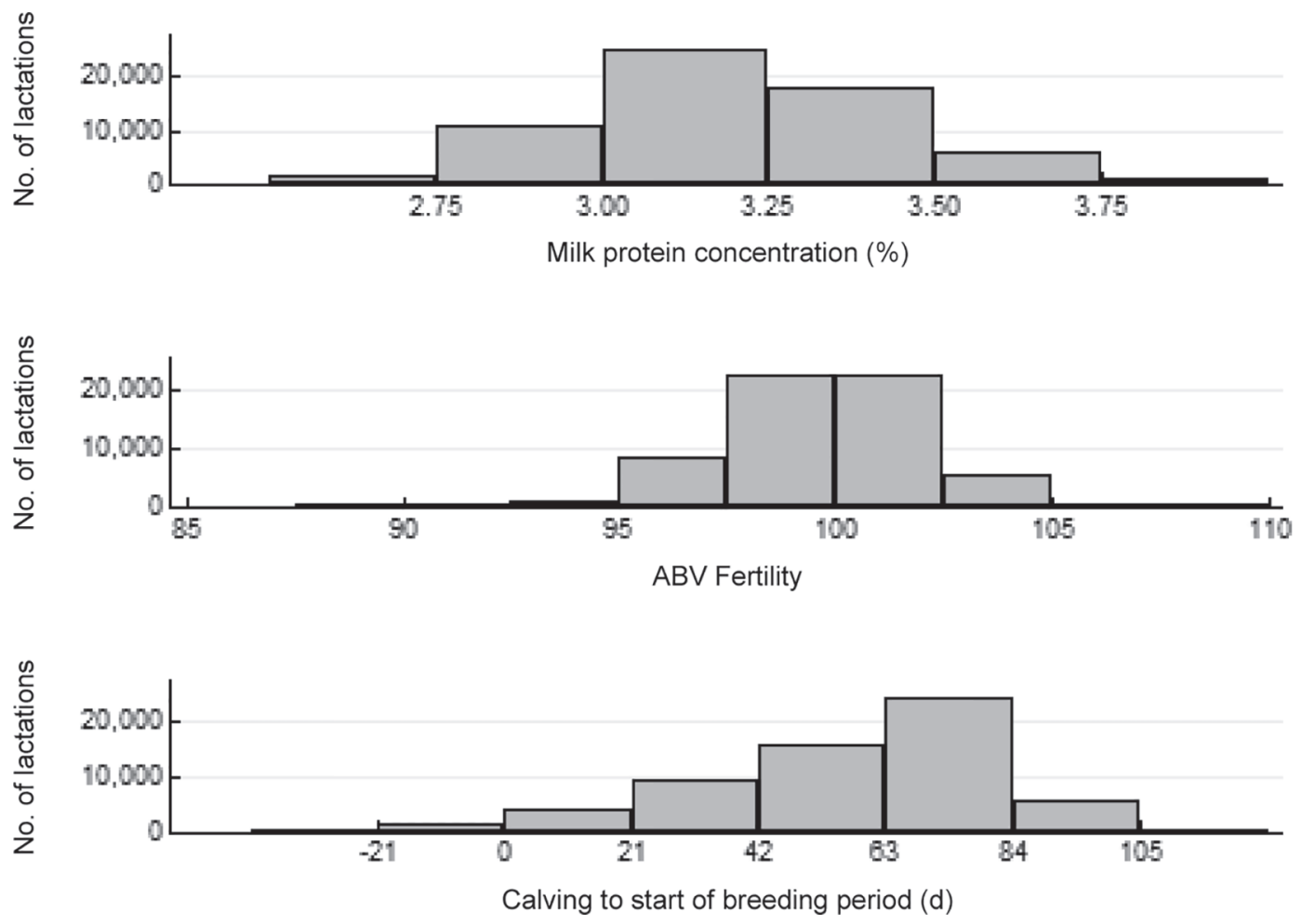

Figure 1. Distributions of 61,741 lactations by milk protein concentration for the first $120 \mathrm{~d}$ of each lactation, the cow's EBV for fertility (Australian breeding value for daughter fertility or ABV fertility) for fertility, and interval from calving to the start of the herd's breeding period. Lactations in which milk protein concentration was $\geq 8 \%$ were excluded from all analyses. In addition, 64 lactations (0.10\%) with milk protein concentrations $\leq 2.5 \%$ and 171 lactations $(0.28 \%)$ with milk protein concentrations $\geq 4.0 \%$ and $<8.0 \%$ were excluded from the upper graph.

mon categories of intervals from calving date to the start of the breeding period (estimates varying from 1.09 to 1.11; results not shown), but there was no large effect of ABV fertility among early calved cows (i.e., those calved $84-120 \mathrm{~d}$ at the start of the breeding period; odds ratio $=0.99 ; 95 \% \mathrm{CI}: 0.93-1.06 ; P=0.840$ ). For lactations in which the cow calved after the start of the breeding period, the odds ratio estimate was 0.94 but very imprecise (95\% CI: 0.68-1.29).

\section{Conceived to First Service}

Milk Protein Concentration. The proportions of cows that conceived to first service increased markedly with milk protein concentration (Tables 3 and 4). This association was independent of ABV fertility (odds ratio $=1.38$ and 1.44 without and with adjustment for ABV fertility, respectively). Strengths of association were similar at various ABV fertility values (odds

Table 3. Percentages of lactations in which the cow conceived to first service based on milk protein concentration (milk protein percentage) for the first $120 \mathrm{~d}$ of each lactation and the cow's EBV for fertility (Australian breeding value for daughter fertility or ABV fertility)

\begin{tabular}{lcccccc}
\hline & \multicolumn{5}{c}{ ABV fertility } \\
\cline { 2 - 7 } Milk protein (\%) & $<95$ & 95 to $<97.5$ & 97.5 to $<100$ & 100 to $<102.5$ & $\geq 102.5$ & Pooled \\
\hline$<2.75$ & $15.1^{1}$ & $29.3^{1}$ & 38.6 & 35.0 & $30.7^{1}$ & 34.3 \\
2.75 to $<3.00$ & $36.3^{1}$ & 29.6 & 35.0 & 36.4 & 38.8 & 35.1 \\
3.00 to $<3.25$ & 34.9 & 32.0 & 36.9 & 38.4 & 40.5 & 37.1 \\
3.25 to $<3.50$ & 36.1 & 35.3 & 39.2 & 39.8 & 43.0 & 39.3 \\
3.50 to $<3.75$ & $41.0^{1}$ & 38.6 & 41.7 & 43.0 & 48.9 & 42.5 \\
$\geq 3.75$ & $42.9^{1}$ & $36.8^{1}$ & 36.7 & 51.1 & $56.0^{1}$ & 44.9 \\
Pooled & 35.2 & 33.2 & 37.7 & 39.1 & 42.3 & 38.0 \\
\hline
\end{tabular}

${ }^{1}$ Denominator (number of lactations) was $<250$; numbers varied from 28 to 245 . Denominators for other nonpooled cells varied from 288 to 7,790 (total $n=52,438$ ). 
Table 4. Effects of a one-percentage-point increase in milk protein concentration at selected values for the cow's EBV for fertility (Australian breeding value for daughter fertility or ABV fertility) on odds of conceiving to first service

\begin{tabular}{lccc}
\hline ABV fertility & Adjusted odds ratio $^{1}$ & $95 \%$ CI & $P$-value \\
\hline All ABV fertility values pooled & & & \\
Not adjusted for ABV fertility & 1.38 & $1.28-1.49$ & $<0.001$ \\
Adjusted for ABV fertility & $1.44^{2}$ & $1.34-1.56$ & $<0.001$ \\
95 & $1.46^{3}$ & $1.25-1.71$ & $<0.001$ \\
100 & $1.44^{3}$ & $1.33-1.56$ & $<0.001$ \\
105 & $1.42^{3}$ & $1.18-1.71$ & $<0.001$ \\
\hline
\end{tabular}

${ }^{1}$ Adjusted for cow age at calving, source of data, year of herd's breeding period start date, and interval from calving to first service (linear and quadratic terms); herd was fitted as a random effect.

${ }^{2}$ Also adjusted for ABV fertility.

${ }^{3}$ Interaction between milk protein concentration and ABV fertility fitted (interaction $P=0.867$ ).

ratios varied from 1.42 to 1.46 ; interaction $P=0.867$ ). These odds ratios were less than those for submission by wk 3 .

The $P$-value for the interaction between milk protein concentration and interval from calving date to the start of the herd's breeding period was $<0.001$. This was largely due to weak but imprecise odds ratio estimates for lactations in which the cow calved close to or after the start of the breeding period. Strengths of association were similar (odds ratios varied from 1.42 to 1.58) among cows that calved longer before the start of the breeding period (Tables 5 and 6 ).

$\boldsymbol{A} \boldsymbol{B} \boldsymbol{V}$ Fertility. Crude percentages of lactations in which the cow conceived to first service for cows with $\mathrm{ABV}$ fertility values of $<95,95$ to $<97.5,97.5$ to $<100,100$ to $<102.5$, and $\geq 102.5$ were $35.2,33.2,37.7$, 39.1 , and $42.3 \%$, respectively (Table 3 ). The $P$-value for the interaction between $\mathrm{ABV}$ fertility and interval from calving date to the start of the herd's breeding period was 0.009 . The adjusted odds ratio for a 2.5 -unit increase in ABV fertility was 1.14 (95\% CI: 1.11-1.16; $P<0.001$ ). Odds ratios were similar for each category of intervals from calving date to the start of the breed- ing period; estimates varied from 1.05 to 1.18 (results not shown). These odds ratios were similar to those for effects of ABV fertility on submission by wk 3 .

\section{Pregnancy by Wk 6}

Milk Protein Concentration. The proportions of cows that became pregnant by wk 6 increased markedly with milk protein concentration (Tables 7 and 8). This association was essentially independent of ABV fertility (odds ratio $=1.94$ and 1.88 without and with adjustment for ABV fertility, respectively). Strengths of association were similar at various ABV fertility values (odds ratios varied from 1.79 to 1.96; interaction $P$ $=0.551)$. The $P$-value for the interaction between milk protein concentration and interval from calving date to the start of the herd's breeding period was 0.329 , and odds ratios for intervals from calving to the start of the breeding period varied from 1.61 to 2.19 (results not shown).

$\boldsymbol{A} \boldsymbol{B} \boldsymbol{V}$ Fertility. Crude percentages of lactations in which the cow became pregnant by wk 6 for cows with $\mathrm{ABV}$ fertility values of $<95,95$ to $<97.5,97.5$ to

Table 5. Percentages of lactations in which the cow conceived to first service based on milk protein concentration (milk protein percentage) for the first $120 \mathrm{~d}$ of each lactation and interval from calving date to the start of the herd's breeding period

\begin{tabular}{lccccccc}
\hline & \multicolumn{7}{c}{ Interval (d) } \\
\cline { 2 - 8 } Milk protein (\%) & $84-120$ & $63-83$ & $42-62$ & $21-41$ & $0-20$ & $<0^{1}$ & Pooled \\
\hline$<2.75$ & $35.3^{2}$ & 40.0 & 32.8 & $24.1^{2}$ & $27.7^{2}$ & $35.7^{2}$ & 34.3 \\
2.75 to $<3.00$ & 41.8 & 40.1 & 33.7 & 26.1 & 26.2 & 33.3 & 35.1 \\
3.00 to $<3.25$ & 43.3 & 41.3 & 35.7 & 28.5 & 27.1 & 35.2 & 37.1 \\
3.25 to $<3.50$ & 44.7 & 43.7 & 38.1 & 30.6 & 25.7 & 31.8 & 39.3 \\
3.50 to $<3.75$ & 50.1 & 47.8 & 42.7 & 31.6 & 24.4 & $25.2^{2}$ & 42.5 \\
$\geq 3.75$ & $47.8^{2}$ & 53.5 & $40.5^{2}$ & $34.0^{2}$ & $26.5^{2}$ & $31.8^{2}$ & 44.9 \\
Pooled & 44.2 & 42.8 & 36.7 & 29.0 & 26.3 & 33.1 & 38.0 \\
\hline
\end{tabular}

${ }^{1}$ Calved after the start of the herd's breeding period.

${ }^{2}$ Denominator (number of lactations) was $<250$; numbers varied from 22 to 232 . Denominators for other nonpooled cells varied from 299 to 8,322 (total $\mathrm{n}=52,438$ ). 
Table 6. Effects of a 1-percentage-point increase in milk protein concentration for the first $120 \mathrm{~d}$ of each lactation at various intervals from calving date to the start of the herd's breeding period on odds of conception to first service

\begin{tabular}{lccr}
\hline Interval $(\mathrm{d})$ & Adjusted odds ratio $^{1}$ & $95 \% \mathrm{CI}$ & $P$-value \\
\hline All intervals pooled & $1.38^{2}$ & $1.28-1.49$ & $<0.001$ \\
$84-120$ & $1.58^{3}$ & $1.26-1.98$ & $<0.001$ \\
$63-83$ & $1.49^{3}$ & $1.32-1.67$ & $<0.001$ \\
$42-62$ & $1.40^{3}$ & $1.21-1.62$ & $<0.001$ \\
$21-41$ & $1.42^{3}$ & $1.16-1.73$ & 0.001 \\
$0-20$ & $0.86^{3}$ & $0.63-1.19$ & 0.366 \\
$<0^{4}$ & $0.72^{3}$ & $0.46-1.12$ & 0.142 \\
\hline
\end{tabular}

${ }^{1}$ Adjusted for cow age at calving, source of data, and year of herd's breeding period start date; herd was fitted as a random effect.

${ }^{2}$ Also adjusted for interval from calving to first service (linear and quadratic terms).

${ }^{3}$ Interaction between milk protein concentration and interval from calving date to the start of the herd's breeding period fitted (interaction $P<0.001)$.

${ }^{4}$ Calved after the start of the herd's breeding period.

$<100,100$ to $<102.5$, and $\geq 102.5$ were $41.3,42.2,46.5$, 51.9 , and $57.1 \%$, respectively (Table 7 ). The $P$-value for the interaction between ABV fertility and interval from calving date to the start of the herd's breeding period was 0.997 . The adjusted odds ratio for a 2.5 -unit increase in ABV fertility was 1.20 (95\% CI: 1.18-1.23; $P<0.001$ ). Odds ratios were similar for each category of intervals from calving date to the start of the breeding period (estimates varying from 1.18 to 1.24 ; results not shown) other than for lactations in which the cow calved after the start of the breeding period; this latter estimate was 1.00 but very imprecise (95\% CI: $0.78-1.28)$.

\section{Pregnancy by Wk 21}

Milk Protein Concentration. The proportions of cows that became pregnant by wk 21 increased markedly with milk protein concentration (Tables 9 and 10). This association was essentially independent of ABV fertility (odds ratio $=1.82$ and 1.77 without and with adjustment for ABV fertility, respectively). Strengths of association were similar at various ABV fertility values (odds ratios varied from 1.59 to 1.91 ; interaction $P$ $=0.367)$. The $P$-value for the interaction between milk protein concentration and interval from calving date to the start of the herd's breeding period was 0.166 , and odds ratios for effects of milk protein concentration at various intervals from calving to the start of the breeding period varied from 1.36 to 2.05 (Table 11).

$\boldsymbol{A} \boldsymbol{B} \boldsymbol{V}$ Fertility. Crude percentages of lactations in which the cow was submitted by wk 3 for cows with ABV fertility values of $<95,95$ to $<97.5,97.5$ to $<100$, 100 to $<102.5$, and $\geq 102.5$ were $74.0,74.8,78.5,82.5$, and $85.2 \%$, respectively (Table 9 ). The $P$-value for the interaction between ABV fertility and interval from calving date to the start of the herd's breeding period was 0.531 . The adjusted odds ratio for a 2.5 -unit increase in ABV fertility was 1.27 (95\% CI: $1.24-1.30 ; P$ $<0.001$ ). Odds ratios were similar within categories of intervals from calving date to the start of the breeding period (estimates varying from 1.20 to 1.32 ; results not shown).

\section{DISCUSSION}

The main finding from this study was that the beneficial associations between milk protein concentration and the 4 measures used to describe reproductive performance in seasonally and split calving herds in Australia were independent of benefits derived from associations involving the ABV fertility. The odds ratios associated with a 1-percentage point increase in milk protein concentration on each measure unadjusted for ABV fertility ranged from 2.02 (submission by wk 3) to 1.38 (conceived to first service; Tables 2, 4, 8, and 10). These changed by only -0.06 to +0.06 after adjusting for ABV fertility. The effects of milk protein concentration on conceived to first service and pregnancy by wk

Table 7. Percentages of lactations in which the cow became pregnant by wk 6 of the herd's breeding period based on milk protein concentration (milk protein percentage) for the first $120 \mathrm{~d}$ of each lactation and the cow's EBV for fertility (Australian breeding value for daughter fertility or ABV fertility)

\begin{tabular}{lcccccc}
\hline & \multicolumn{5}{c}{ ABV fertility } \\
\cline { 2 - 7 } Milk protein (\%) & $<95$ & 95 to $<97.5$ & 97.5 to $<100$ & 100 to $<102.5$ & $\geq 102.5$ & Pooled \\
\hline$<2.75$ & $17.2^{1}$ & 32.0 & 36.2 & 40.5 & $27.1^{1}$ & 35.5 \\
2.75 to $<3.00$ & 40.2 & 34.3 & 39.8 & 45.3 & 49.1 & 41.7 \\
3.00 to $<3.25$ & 39.9 & 40.7 & 45.2 & 50.8 & 55.2 & 47.5 \\
3.25 to $<3.50$ & 45.1 & 47.4 & 50.8 & 55.1 & 60.5 & 52.9 \\
3.50 to $<3.75$ & $55.2^{1}$ & 49.4 & 54.1 & 58.7 & 66.4 & 56.6 \\
$\geq 3.75$ & $48.3^{1}$ & $50.3^{1}$ & 49.4 & 64.3 & $67.7^{1}$ & 57.5 \\
Pooled & 41.3 & 42.2 & 46.5 & 51.9 & 57.1 & 48.8 \\
\hline
\end{tabular}

${ }^{1}$ Denominator (number of lactations) was $<250$; numbers varied from 29 to 173 . Denominators for other nonpooled cells varied from 253 to 9,174 (total $n=61,741$ ). 
Table 8. Effects of a 1-percentage-point increase in milk protein concentration at selected values for the cow's EBV for fertility (Australian breeding value for daughter fertility or ABV fertility) on odds of pregnancy by wk 6 of the herd's breeding period

\begin{tabular}{lccc}
\hline ABV fertility & Adjusted odds ratio & 95\% CI & $P$-value \\
\hline All ABV fertility values pooled & & & \\
Not adjusted for ABV fertility & 1.94 & $1.80-2.09$ & $<0.001$ \\
Adjusted for ABV fertility & $1.88^{2}$ & $1.75-2.03$ & $<0.001$ \\
95 & $1.96^{3}$ & $1.68-2.30$ & $<0.001$ \\
100 & $1.87^{3}$ & $1.74-2.02$ & $<0.001$ \\
105 & $1.79^{3}$ & $1.49-2.15$ & $<0.001$
\end{tabular}

${ }^{1}$ Adjusted for cow age at calving, source of data, year of herd's breeding period start date, and interval from calving date to the start of the herd's breeding period (linear and quadratic terms); herd was fitted as a random effect.

${ }^{2}$ Also adjusted for ABV fertility.

${ }^{3}$ Interaction between milk protein concentration and $\mathrm{ABV}$ fertility fitted (interaction $P=0.551$ ).

6 and 21 as reflected by these odds ratios were similar for the 3 selected ABV fertility values $(95,100$, and $105)$, and the $P$-values for the interactions between milk protein concentration and ABV fertility were high $(P$ values for interaction varied from 0.367 to 0.867 ; Tables $4,8$, and 10$)$. The exception was the interaction involving the effects of milk protein concentration and ABV fertility on submission by wk 3 (interaction $P=0.008$; Table 2). Although the effect of milk protein concentration on submission by wk 3 was always substantial and significantly positive, the odds ratios varied from 2.47 among cows with an ABV fertility of only 95 to 1.53 for those with an ABV fertility of 105 (Table 2). This indicated that the greatest effect of a $1 \%$ increase in milk protein concentration on submission by wk 3 was with cows with lower ABV fertility values (Figure 2).

The current analyses demonstrate that the positive associations of milk protein concentration and ABV fertility with reproductive performance are largely independent. Consequently, the effects of milk protein concentration and ABV fertility on the 4 measures of reproductive performance studied are jointly multiplicative on the odds ratio scale (Tables 2, 4, 8, and 10). Accordingly, our major conclusion is that research should be conducted to understand the component of the relationship not being captured by ABV fertility. This research could lead to management strategies that capture at least some of this additional component of the relationships. This additional component probably has genetic and nongenetic parts. In an unpublished study, covariance components of the relationship were assessed [J. M. Morton (Jemora Pty Ltd, Geelong, Victoria, Australia), M. Haile-Mariam (Agriculture Victoria, AgriBio, Centre for AgriBioscience, Bundoora, Victoria, Australia), and J. E. Pryce (Agriculture Victoria, AgriBio, Centre for AgriBioscience, Bundoora, Victoria, Australia), unpublished data]. This research showed that approximately half of the total covariance is genetic. The ABV fertility will capture some of this component but probably not all of it, and captures none of the environmental components (permanent environmental effects of cow, herd-year-season, and residual) of the relationship.

Results from the current study also show that cows with higher ABV fertility values have markedly better reproductive performance. With increases in ABV fertility from $<95$ to $\geq 102.5$, crude submission rate by wk 3 increased from 60.0 to $71.6 \%$ (Table 1), conception

Table 9. Percentages of lactations in which the cow became pregnant by wk 21 of the herd's breeding period based on milk protein concentration (milk protein percentage) for the first $120 \mathrm{~d}$ of each lactation and the cow's EBV for fertility (Australian breeding value for daughter fertility or ABV fertility)

\begin{tabular}{lcccccc}
\hline & \multicolumn{5}{c}{ ABV fertility } \\
\cline { 2 - 7 } Milk protein $(\%)$ & $<95$ & 95 to $<97.5$ & 97.5 to $<100$ & 100 to $<102.5$ & $\geq 102.5$ & Pooled \\
\hline$<2.75$ & $63.9^{1}$ & $61.9^{1}$ & 64.8 & 69.9 & $71.4^{1}$ & 66.5 \\
2.75 to $<3.00$ & 70.0 & 69.2 & 72.6 & 78.1 & 79.9 & 74.6 \\
3.00 to $<3.25$ & 73.8 & 73.5 & 78.2 & 82.3 & 83.5 & 79.5 \\
3.25 to $<3.50$ & 76.0 & 78.5 & 81.7 & 84.8 & 87.7 & 83.0 \\
3.50 to $<3.75$ & $84.1^{1}$ & 82.1 & 84.5 & 86.0 & 90.8 & 85.5 \\
$\geq 3.75$ & $82.8^{1}$ & $80.6^{1}$ & 80.9 & 88.5 & $91.6^{1}$ & 85.2 \\
Pooled & 74.0 & 74.8 & 78.5 & 82.5 & 85.2 & 80.0 \\
\hline
\end{tabular}

${ }^{1}$ Denominator (number of lactations) was $<250$; numbers varied from 29 to 247 . Denominators for other nonpooled cells varied from 280 to 8,905 (total $\mathrm{n}=60,206$ ). 
Table 10. Effects of a 1-percentage-point increase in milk protein concentration for the first $120 \mathrm{~d}$ of each lactation at selected values for the cow's EBV for fertility (Australian breeding value for daughter fertility or ABV fertility) on odds of pregnancy by wk 21 of the herd's breeding period

\begin{tabular}{lccc}
\hline ABV fertility & Adjusted odds ratio $^{1}$ & $95 \%$ CI & $P$-value \\
\hline All ABV fertility values pooled & & & \\
Not adjusted for ABV fertility & 1.82 & $1.66-2.00$ & $<0.001$ \\
Adjusted for ABV fertility & $1.77^{2}$ & $1.61-1.94$ & $<0.001$ \\
95 & $1.91^{3}$ & $1.57-2.31$ & $<0.001$ \\
100 & $1.74^{3}$ & $1.58-1.92$ & $<0.001$ \\
105 & $1.59^{3}$ & $1.25-2.03$ & $<0.001$ \\
\hline
\end{tabular}

${ }^{1}$ Adjusted for cow age at calving, source of data, year of herd's breeding period start date, and interval from calving date to the start of the herd's breeding period (linear and quadratic terms); herd was fitted as a random effect.

${ }^{2}$ Also adjusted for ABV fertility.

${ }^{3}$ Interaction between milk protein concentration and ABV fertility fitted (interaction $P=0.367$ ).

rate to first insemination increased from 35.2 to $42.3 \%$ (Table 3), 6-wk pregnancy rate increased from 41.3 to $57.1 \%$ (Table 7 ), and 21-wk pregnancy rate increased from 74.0 to $85.2 \%$ (Table 9). The adjusted odds ratio across all of these ABV fertility groups ranged from 1.09 for submission by wk 3 to 1.27 for pregnancy by wk 21 $(P<0.001$ in every case). These increases are the first published results to demonstrate the phenotypic effectiveness of the recent modifications in calculating ABV fertility values (Pryce et al., 2013). An increasing number of Holstein sires have ABV fertility values $>102.5$, providing herd owners with greater ability to achieve even higher wk 6 and 21 pregnancy rates through sire selection decisions over and above the effects of any management strategies that use the component of the relationship not being captured by ABV fertility.

Reproductive performance has also been compared between cows with low and high values for another breeding value. Cummins et al. (2012a) reported that

Table 11. Effects of a 1-percentage-point increase in milk protein concentration for the first $120 \mathrm{~d}$ of each lactation at various intervals from calving date to the start of the breeding period on odds of pregnancy by wk 21 of the herd's breeding period

\begin{tabular}{lccr}
\hline Interval $^{(d)}$ & Adjusted odds ratio $^{1}$ & $95 \% \mathrm{CI}$ & $P$-value \\
\hline All intervals pooled & $1.82^{2}$ & $1.66-2.00$ & $<0.001$ \\
$84-120$ & $1.36^{3}$ & $1.02-1.82$ & 0.037 \\
$63-83$ & $2.05^{3}$ & $1.76-2.40$ & $<0.001$ \\
$42-62$ & $1.76^{3}$ & $1.47-2.12$ & $<0.001$ \\
$21-41$ & $1.95^{3}$ & $1.57-2.43$ & $<0.001$ \\
$0-20$ & $1.77^{3}$ & $1.34-2.35$ & $<0.001$ \\
$<0^{4}$ & $1.47^{3}$ & $1.01-2.15$ & 0.046 \\
\hline
\end{tabular}

$\overline{{ }^{1} \text { Adjusted for cow age at calving, source of data, and year of herd's }}$ breeding period start date; herd was fitted as a random effect.

${ }^{2}$ Also adjusted for interval from calving date to the start of the herd's breeding period (linear and quadratic terms).

${ }^{3}$ Interaction between milk protein concentration and interval from calving date to the start of the herd's breeding period fitted (interaction $P=0.166$ ).

${ }^{4}$ Calved after the start of the herd's breeding period. cows of high genetic merit for fertility (Fert+) had higher conception rates to first insemination $(+22.3 \%)$, 6 -wk pregnancy rates $(+31 \%)$, and 20 -wk pregnancy rates $(+16.7 \%)$ and required $11.1 \mathrm{~d}$ less to recalve (shorter calving interval) compared with cows of lower genetic merit (Fert-). The higher 6-wk pregnancy rate in the Fert+ cows ( $72.2 \%$ vs. $41.2 \%)$ was influenced more by the $22.3 \%$ increase in first insemination conception rate $(55.6 \%$ vs. $33.3 \%)$ than by the $11.1 \%$ increase in 3 -wk submission rate $(83.3 \%$ vs. $72.2 \%$; Cummins et al., 2012a). Both percentages are higher than those recorded for the Holstein cows in the current data that had $\mathrm{ABV}$ fertility values $\geq 102.5(71.6 \%)$ or $<95$ (60\%; Table 1). The lower submission rates reported by Cummins et al. (2012a) were attributable to delays in resumption of cyclicity postpartum and estrus

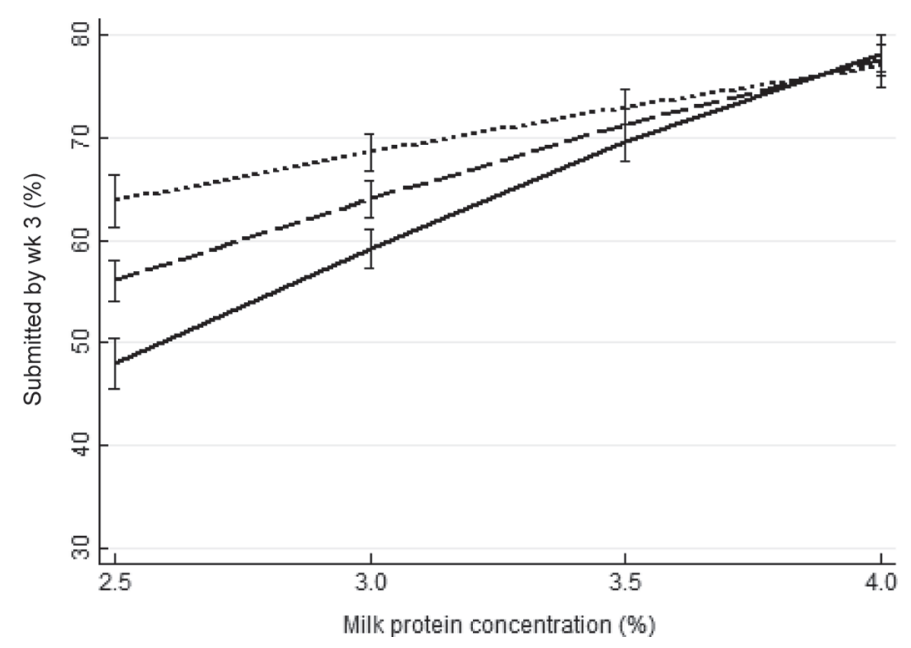

Figure 2. Estimated proportions (expressed as percentages) of lactations in which the cow was submitted by wk 3 of the herd's breeding period by milk protein concentration for the first $120 \mathrm{~d}$ of each lactation at various cow EBV for fertility (Australian breeding value for daughter fertility or ABV fertility). Solid line = value of 95; long dashed line $=$ value of 100 ; short dashed line $=$ value of 105. Error bars indicate standard error of the means. 
expression. Moore et al. (2014) reported that $86 \%$ of Fert+ cows had resumed cyclicity by wk 6 postpartum compared with only $20 \%$ of the Fert- cows. In a similar study, Cummins et al. (2012b) reported that $22 \%$ of the Fert- cows ovulated without being detected in estrus compared with only $2 \%$ of the Fert+ cows.

The interval from calving until the date of the start of the herd's breeding period in a seasonally calving herd is the major factor affecting the probabilities of submission by wk 3, conception to first insemination, and pregnancy by wk 6 and 21 (Morton, 2004). In the case of 3 -wk submission rate, this interval interacts with the interval from calving to first estrus to influence the probability of a cow being detected in estrus and inseminated by wk 3 of the herd's breeding period. Cows with short intervals from calving until the start of the herd's breeding period are less likely to be detected in estrus and inseminated by wk 3, partly because they are less likely to have had their first postpartum estrus by wk 3 of the herd's breeding period. These same 2 intervals also influence the probability of conception to first service because cows that have had a preinsemination estrus have a higher probability of conceiving to first insemination (Macmillan and Clayton, 1980). In the current study, we assessed the extent of any interactions between the interval from calving date to the first day of the herd's breeding period and either milk protein concentration or $\mathrm{ABV}$ fertility; to our knowledge, ours is the first reported study to assess this. The associations involving milk protein concentration and ABV fertility with each of the 4 measures of reproductive performance are positive over most intervals from calving until the date for the start of the herd's breeding period; in the current study, these intervals ranged from $120 \mathrm{~d}$ to negative intervals (where the cow calved after the date of the start of the herd's breeding period). An increase of $1 \%$ in milk protein concentration significantly increased the probabilities of submission by wk 3 and pregnancy by wk 6 and 21 , with nonsignificant interactions (interaction $P=$ 0.166-0.638) between milk protein concentration and generally similar odds ratios for the selected intervals to the start of the herd's breeding period. By contrast, there was evidence of interaction between milk protein concentration and the selected intervals from calving to the start of the herd's breeding period on conception to first service (interaction $P<0.001$; Table 6 ). This was because the odds ratios for cows calving either during the $20 \mathrm{~d}$ preceding the first day of the herd's breeding period or after that date (Table 6 ) were not significant (odds ratio estimates were 0.86 and 0.72 , respectively), whereas the odds ratios for the other 4 intervals were well above 1.0, varying from 1.40 to 1.58 . Thus, the effect of milk protein concentration on the probability of conception to first insemination was minimal in cows with short intervals to the start of the herd's breeding period but markedly positive and similar in cows with various longer intervals (the more common categories; Table 5). Effects of ABV fertility on these reproductive performance measures were also similar for the most common categories of intervals from calving date to the start of the herd's breeding period. These results show that the mechanisms causing the associations between milk protein concentration and reproductive performance are operating in cows with a wide range of intervals from calving date to the start of the herd's breeding period even though that interval itself has large effects on reproductive performance. The same applies to mechanisms contributing to the associations between ABV fertility and reproductive performance.

Even though milk protein concentration is quite highly heritable (Simm, 1998; Haile-Mariam and Goddard, 2008) and its positive associations with measures of reproductive performance in seasonally calving herds are recognized, it has not been incorporated into multitrait models for calculating genetic merit for fertility. Haile-Mariam et al. (2003) found that milk protein concentration was favorably correlated both genetically and environmentally with calving interval. However, the genetic correlation between calving interval and milk protein concentration was slightly weaker than that between calving interval and other milk yield traits. Consequently, milk protein concentration did not improve the reliability of ABV fertility estimates based on calving interval. Although Harris and Pryce (2004) confirmed that milk protein concentration was a good phenotypic indicator of fertility, the genetic correlations with their 2 selected measures of reproductive performance for cows in New Zealand herds were weak $(<0.21)$ compared with BCS $(>0.38)$. Their 2 measures of reproductive performance were the probability of being inseminated in the first $3 \mathrm{wk}$ of the herd's breeding period and the probability of the cow having a calf sired by AI. It is possible that the largest benefits of incorporating milk protein concentration into multitrait models for calculating genetic merit for fertility are for sires with daughters with only limited reproductive data.

Irrespective of studies to capture the strong positive associations involving milk protein concentration and measures of reproductive performance in dairy herd management, consideration should also be given to calculating an index that herd owners could use to identify cows with differing probabilities for submission by wk 3 and for conceiving to first insemination. The index could amalgamate data for calving date, milk protein concentration, and ABV fertility for individual cows within a herd. Each of these measures is positively as- 
sociated with submission by wk 3 , conception to first insemination, and pregnancy by wk 6 and 21 . This index could be used to identify cows most at risk of anestrus as well as cows with a higher probability of conceiving when using expensive semen or sexed semen with lower fertility. Identifying cows most at risk is an issue of increasing importance in seasonally calving herds in Australia. Shephard (2005) estimated that between 20 and $30 \%$ of cows in Victorian herds experience a period of anestrus that will delay submission. This incidence had increased to $44 \%$ by 2013 (Plozza et al., 2016). The latter authors identified age, BCS, and DIM as key risk factors. However, data for milk protein concentration and ABV fertility for individual cows are available in many herds that have production and ancestry records that could be added to BCS data where it is available.

Because the positive associations involving milk protein concentration and ABV fertility with the 4 selected reproductive measures are independent phenotypically (Tables 1-4 and Tables 7-10), they probably have different causal mechanisms. However, some metabolic pathways may be involved in both associations. For both milk protein concentration and genetic merit for fertility, associations with reproductive performance may be due, in part, to differences in metabolic hormones, including IGF-1 and insulin (Cummins et al., 2012a; Moore et al., 2014; Douglas et al., 2016). Douglas et al. (2016) reported that first-lactation Holstein cows in the highest quartile for milk protein concentration up to 120 DIM had higher concentrations of IGF-1, insulin, and glucose. Cummins et al. (2012a) and Moore et al. (2014) also reported higher concentrations of the same 3 components in Fert+ cows compared with Fert- cows. These higher concentrations in the latter study were not associated with differences in milk protein concentration. The similarity in results for the cows with higher milk protein concentration and the Fert+ cows also involved their ability to maintain higher BCS during early lactation. It is likely that some of the additional differences identified by Cummins et al. (2012a,b) and Moore et al. (2014), such as the lower incidence of ovulation without estrus, shorter postcalving interval to first estrus, and improved postpartum uterine health in Fert+ cows, may also be present in cows producing milk with above-average milk protein concentration.

\section{CONCLUSIONS}

Milk protein concentration has a strong positive association with reproductive performance in dairy cows. Mechanisms contributing to the association between milk protein concentration and conception to first service and pregnancy by wk 6 and 21 appear to differ from the mechanisms contributing to the effects of ABV fertility on these same measures, but some metabolic pathways may be involved in both associations. Thus, if the former causes can be determined and used through management changes, beneficial effects on reproductive performance would be expected over and above the benefits of increased ABV fertility alone. Milk protein concentration and ABV fertility associations with submission by wk 3 may reflect different mechanisms at lower values of each but related mechanisms at higher values. Increases in sire ABV fertility have important beneficial effects on reproductive performance. These effects are mediated through increases in both probability of submission and probability of conception to each insemination. For cows calved before the start of the herd's breeding period, the effects of increases in both milk protein concentration and ABV fertility benefit cows regardless of their interval from calving to the start of the breeding period. These findings demonstrate the potential for increasing reproductive performance through identifying the causes of the positive associations between milk protein concentration and each of these 4 measures of reproductive performance and then devising management strategies to capitalize on them. We conclude that research should be conducted to understand the component of the relationship not being captured by ABV fertility. This research could lead to management strategies that capture at least some of this additional component of these relationships.

\section{ACKNOWLEDGMENTS}

We gratefully acknowledge the assistance of the veterinarians who supplied data for this study: Jakob Malmo (Maffra Veterinary Centre, Maffra, Victoria, Australia), Peter Younis and Dave Colson (The Vet Group, Timboon and Warrnambool, Victoria, Australia), Steve Jagoe (Warrnambool Veterinary Clinic, Warrnambool, Victoria, Australia), and Neil Leighton (Smithton Veterinary Services, Smithton, Tasmania, Australia). We also acknowledge the Australian Dairy Herd Improvement Scheme (ADHIS, Melbourne, Australia) and Paul Koh, who supplied data from the ADHIS database. This study was partly funded by the Department of Economic Development, Jobs, Transport and Resources, Government of Victoria (Victoria, Australia).

\section{REFERENCES}

Barber, D. G. 2007. Factors affecting milk protein concentration and composition of dairy cattle in the sub-tropical regions of northern Australia. PhD Thesis. The University of Queensland, Brisbane, Australia. Accessed Dec. 20, 2016. http://espace.library.uq.edu. $\mathrm{au} / \mathrm{view} / \mathrm{UQ}: 151571$. 
Buckley, F., K. O'Sullivan, J. F. Mee, R. D. Evans, and P. Dillon. 2003. Relationships among milk yield, body condition, cow weight and reproduction in spring-calved Holstein-Friesians. J. Dairy Sci. 86:2308-2319.

Cummins, S. B., P. Lonergan, A. C. O. Evans, D. P. Berry, R. D. Evans, and S. T. Butler. 2012a. Genetic merit for fertility traits in Holstein cows: I. Production characteristics and reproductive efficiency in a pasture-based system. J. Dairy Sci. 95:1310-1322.

Cummins, S. B., P. Lonergan, A. C. O. Evans, and S. T. Butler. 2012b. Genetic merit for fertility traits in Holstein cows: II. Ovarian follicular and corpus luteum dynamics, reproductive hormones, and estrus behaviour. J. Dairy Sci. 95:3698-3710.

Douglas, M. L., L. C. Marett, K. L. Macmillan, J. M. Morton, M. C. Hannah, A. D. Fisher, and M. J. Auldist. 2016. Associations of high and low milk protein concentrations with energy allocation, milk production, and concentrations of blood plasma metabolites and hormones in Holstein-Friesian cows. J. Dairy Sci. 99:1005710066.

Haile-Mariam, M., and M. E. Goddard. 2008. Genetic and phenotypic parameters of lactations longer than 305 days (extended lactations). Animal 2:325-335.

Haile-Mariam, M., J. M. Morton, and M. E. Goddard. 2003. Can milk protein percentage or yield serve as indicator of fertility (calving interval) in dairy cattle? Proc. Assoc. Adv. Anim. Breed. Genetics. 15:72-76.

Harris, B. L., and J. E. Pryce. 2004. Genetic and phenotypic relationships between milk protein percentage, reproductive performance and body condition score in New Zealand dairy cattle. Proc. N.Z. Soc. Anim. Prod. 64:127-131.

Macmillan, K. L., and D. G. Clayton. 1980. Factors influencing the interval to post-partum oestrus, conception date and empty rate in an intensively managed dairy herd. Proc. N.Z. Soc. Anim. Prod. 40:236-239.

Madouasse, A., J. N. Huxley, W. J. Browne, A. J. Bradley, I. L. Dryden, and M. J. Green. 2010. Use of individual cow milk recording data at the start of lactation to predict the calving to conception interval. J. Dairy Sci. 93:4677-4690.

Moore, S. G., T. Fair, P. Lonergan, and S. T. Butler. 2014. Genetic merit for fertility traits in Holstein cows: IV. Transition period, uterine health, and resumption of cyclicity. J. Dairy Sci. 97:27402752 .

Morton, J. 2011. InCalf Fertility Data Project 2011. Dairy Australia, Melbourne, Victoria, Australia.

Morton, J. M. 2004. Determinants of reproductive performance of dairy cows in commercial herds in Australia. PhD Thesis. University of Melbourne, Melbourne, Australia. Accessed Oct. 15, 2015. http://hdl.handle.net/11343/38864.

Morton, J. M. 2010. Interrelationships between herd-level reproductive performance measures based on intervals from initiation of the breeding program in year-round and seasonal calving dairy herds. J. Dairy Sci. 93:901-910.

Morton, J. M., M. J. Auldist, M. L. Douglas, and K. L. Macmillan. 2016. Associations between milk protein concentration at various stages of lactation and reproductive performance in dairy cows. J. Dairy Sci. 99:10044-10056.

Opsomer, G., Y. T. Grohn, J. Hertl, M. Coryn, H. Deluyker, and A. de Kriuf. 2000. Risk factors for post-partum ovarian dysfunction in high producing dairy cows in Belgium: A field study. Theriogenology $53: 841-857$.

Plozza, K. L., D. S. Beggs, P. D. Mansell, M. A. Stevenson, C. B. Blackwood, and M. F. Pyman. 2016. Postpartum anoestrus in five seasonally-calving dairy farms in Victoria, Australia. Aust. Vet. J. 94:293-298.

Pryce, J. E., M. Haile-Mariam, P. Bowman, T. Nguyen, K. Konstantinov, G. J. Nieuwhof, and B. J. Hayes. 2013. Improving the reliability of fertility breeding values in Australian dairy cattle. Proc. Assoc. Adv. Anim. Breed. Genetics. 20:33-36.

Shephard, R. W. 2005. A comparison of performance of the Ovsynch treatment program between cycling and non-cycling cows within seasonally-calving dairy herds. Aust. Vet. J. 83:751-757.

Simm, G. 1998. Genetic Improvement of Cattle and Sheep. Farming Press, Ipswich, UK.

Xu, Z. Z., and L. J. Burton. 2003. Reproductive Performance of Dairy Cows in New Zealand. Final Report of the Fertility Monitoring Group. Livestock Improvement Corporation, Hamilton, New Zealand. 